Research Report

515

\title{
ACOUSTIC EMISSION MONITORING OF WELDMENTS
}

by

Theodore Hopwood II

Senior Research Engineer

and

James H. Havens

Director of Research

Division of Research

Bureau of Highways

DEPARTMENT OF TRANSPORTATION

Commonwealth of Kentucky

accepted for publication by the

American soclety for Testing Materials

December 1978 


\title{
ACOUSTIC EMISSION MONITORING \\ OF WELDMENTS
}

by

Theodore Hopwood II and James H. Havens

\begin{abstract}
Weld tests were performed on low-carbon and high-strength, low-alloy steel weldments. The weldments were monitored with an acoustic emission detector during both the 'in-process' and the 'in-cooling' phases of the welding operation. Artificial defects were induced in several of the welds to promote cracking. Some high-strength weldments were designed to produce welds subject to high restraint.

Nondestructive and destructive evaluation of the completed weldments revealed that high acoustic emission activity 'in-cooling' could be correlated with embedded defects and cold-cracking. Copius emission activity was also detected from unflawed weldments. Acoustic emissions were detected in high-strength steel weldments for periods up to 265 hours. However, there was no clear relation between the duration of acoustic emission activity and cracking. On a per-electrode-deposited basis, high-stressed welds produced more emissions than low-stressed welds.

Keywords: Acoustic emission, Fracture, Non-destructive evaluation, Restraint, Steel, Welding.
\end{abstract}




\section{INTRODUCTION}

Acoustic emissions ( $A E)$ are high-frequency stress waves generated by dynamic, internal stress changes in a material. The stress waves travel from their source to the surface of an internally-stressed material where they can be detected. Most stress waves lack sufficient strength to be detected audibly. Therefore, sensitive electronic equipment must be used to detect $A E$ activity. Ultrasonic frequencies, usually above $100 \mathrm{kHz}$, are monitored to avoid audible interference and mechanical noise.

Most previous AE weld tests have used special-purpose, high-strength alloys and slagless welding methods which made the results difficult to relate to bridge steel fabrication application (1-6). Also, there was an emphasis by most of the researchers to detect hot cracking 'in-process' (during weld depostion). While these efforts showed much promise, additional exploratory work was needed to investigate the dynamic behavior of weldments using materials and fabrication processes related to the interests of the Kentucky Bureau of Highways.

This report describes the application of AE monitoring to structural steel specimens using the manual, shielded metal-arc process. The work was conducted by the Bureau of Highways, Division of Research, from 1973-1976. Three series of tests were performed using (1) low-restraint, butt-welded plates of low-carbon steel, (2) low-restraint, butt-welded plates of high-strength steel, and (3) high-restraint (cruciform and Lehigh) weldments of high-strength steel. A comparison is made between the recorded $A E$ data and subsequent examinations of the weldments.

\section{THE AE MONITORING SYSTEM}

The test device used in this study was a Dunegan Model 3000 acoustic emission monitor. The $A E$ monitor, as shown in Figure 1, consists of a variety of modular $A E$ signal processing components, preamplifiers, and receivers (transducers). Transducers were attached to a weldment with magnets, and a polyester resin, Dow Chemical DV-9, was used between the transducer and the weldment to achieve good acoustical coupling. When stimulated by stress waves, transducers emitted low-voltage electrical signals proportional to the magnitude and intensity of the impressed stress waves.

The electrical signals were magnified by preamplifiers before being transmitted to counting devices, the Dunegan 301 and 310 totalizers. In the totalizers, signals were re-amplified, band-pass filtered, conditioned, and sent through a threshold detector. Each 
time a signal peak exceeded a set voltage level in the threshold detector, counter logic circuits recorded this as one $A E$ count. This type of $A E$ signal processing is known as ring-down counting. The counts were summed or used in conjunction with a Dunegan Model 402 reset clock to provide a rate indication (number of $A E$ counts recorded in a given time interval). The AE activity was visually displayed on LED's, stored on a two-pen strip-chart recorder, and audibly replicated by a Dunegan Model 702 audio monitor.

\section{ACOUSTIC EMISSION TESTS}

For the first series of tests, six sets of ASTM A 36 plates, $1 / 2 \times 24 \times 12$ in. (12.7 $\times 609.6 \times 304.8 \mathrm{~mm}$ ), were cut for butt welds using a $30^{\circ}$ single bevel with a $1 / 8$-in. $(3.2-\mathrm{mm})$ relief along the 24-in. $(609.6-\mathrm{mm})$ length. The plates were torch cut and beveled. AWS E6012 and E7014 electrodes were used.

Both AE totalizers were used for the weld tests. The Dunegan Model 301 totalizer was operated 'in-process' in the rate mode over a 2-second summing interval. This totalizer used a special, electric, noise-rejecting transducer, a Dunegan D-140, having a resonant frequency of $200 \mathrm{kHz}$. The signals were band-pass filtered between $100-300 \mathrm{kHz}$. The Model 310 totalizer was operated 'in cooling' in the summing mode using a regular, single-ended Dunegan S-140 transducer. Each AE counting system had a total signal amplification of $85 \mathrm{~dB}$.

Before each test, both transducers were attached on the outer edge of one plate. The plates were then tack welded together. A root pass was made, followed by one or two cover passes to fill the weld groove. The weldment was turned over and a back pass was deposited. After each pass, the weld bead was completely de-slagged by chipping and brushing. 'In-process' testing was conducted by AE monitoring of the plate when the weld operator struck an arc and deposited metal. 'In-cooling' testing was performed by continuous $\mathrm{AE}$ monitoring of the completed weldment during cooling. In some cases, monitoring was run continuously for 12 hours after the weld was completed. Each weld was made with DC straight polarity and amperage(s) which would provide complete penetration welds.

Test Weld 1 was intended to be satisfactory. However, after the root pass, several fisheyes were found, filled with slag, which could not be removed by chipping. The amperage on the initial cover pass was increased in an effort to remelt the partially entrapped slag and float it to the surface of the new weld bead. After welding was 
completed, the quality of the weld was questionable. Test Weld 2 was another attempt to produce a perfect weld. Problems of the partially entrapped slag reoccurred. The welding amperage was again increased, but the quality of the completed weld was also unknown. Test Weld 3 was run at a higher amperage than Welds 1 and 2 . The weld bead was uniform and the slag was easily removed from the weld bead by brushing. This test was acceptable from a process control standpoint. Weld 4 was prepared to study the AE response of entrapped slag. Most of the slag between the first and second cover pass was not chipped. However, the amperage of the second cover pass was excessive. It melted most of the slag, floating much of it to the top of the weld bead where it was removed. Test Weld 5 was prepared to study the AE response of a rapidly cooled weld. After each pass, the weldment was deslagged. Before removing the slag from the last pass, the weld was water quenched. In Weld 6, the root pass was deposited and not chipped. The weld groove was then 'slugged' with AWS E6012 electrodes and covered with another weld pass.

Several difficulties were encountered with 'in-process' AE monitoring. Auxiliary tests revealed that the major source of acoustic activity at high signal gains was due to slag cracking. This could not be separated from AE activity of the weldment using the available equipment. However, Prine has had good success monitoring 'in-process' welds using a more advanced $A E$ system (6). Subsequent tests employed only 'in-cooling' AE monitoring.

High-strength structural steels, ASTM A 588 and A 514, were chosen for the second and third series of tests. AWS E7016 $\mathrm{C} 1$ electrodes were used for the tests on the A 588 steel. AWS E11018-M electrodes were selected for the A 514 steel.

The second series of tests were unrestrained butt welds using 24-inch by 16-inch $(610-\mathrm{mm}$ by $410-\mathrm{mm})$ plates having a root opening bevel of $45^{\circ}$ and $1 / 8$-inch $(3-\mathrm{mm})$ by 2 -inch $(51-\mathrm{mm})$ backing bars along the 24 inch $(610-\mathrm{mm})$ length. Both types of steels were tested in this configuration.

For this second series of tests, the Dunegan 301 totalizer was used with a single-ended, Dunegan S-140 transducer. The system gain was initially set at $85 \mathrm{~dB}$. The AE signals were band-pass filtered between $100-300 \mathrm{kHz}$. Acoustic emissions were stored on a strip-chart recorder during the tests.

The initial tests were butt welds of A 514 plates using a DC welding machine. The welding amperage was adjusted for full-penetration welds. The plate gap was set at 1/8 inch $(3 \mathrm{~mm})$. Backing bars had 2-inch $(51-\mathrm{mm})$ run-off tabs on one side of the groove to start the weld. Electrodes were deposited as stringer beads along the groove. The slag 
was chipped and wire brushed before depositing a cover pass. After the last surface bead was chipped, the transducer was attached to the weldment and the plate was monitored as it cooled.

At the onset of welding, several problems were encountered. The weld beads, especially root passes, had a large amount of porosity. Porosity in the initial passes usually led to its subsequent formation in the covering beads. This made it difficult to achieve a good weldment. The condition was finally alleviated by changing electrode size for different passes and reducing the amperage towards the minimum values specified by the electrode manufacturer. Other problems were related to the acoustic emission equipment and test procedure. Electric noise from surrounding equipment created false recordings. The noise, caused by switching circuits located in the building, did not greatly affect the count total due to their small magnitude and infrequent occurrence. However, such activity masked termination of emissions from the weldment. To overcome the problem, low-noise Dunegan D-140 transducers were substituted and the system gain was reduced from 85 to $80 \mathrm{~dB}$. A test was considered finished when no acoustic emissions could be detected from the weldment for a period of 24 hours.

The A 588 plates were welded with less difficulty than encountered with the A 514 steels. The welding amperages were adjusted for full penetration. Backing bars were used and the weld beads were applied as stringers. The welds were made using $3 / 16$-inch $(5-\mathrm{mm})$ electrodes for all passes. Wet or unbaked electrodes were used in several tests, attempting to induce hydrogen-promoted cracking.

Two types of high-restraint weldments were selected for the third series of tests. The A 588 steel was used in the Lehigh restraint specimen, shown in Figure 2, with full restraint. A single electrode pass was made in the slot with the $20^{\circ}$ bevel. The $A$ 514 steel was employed in the cruciform test shown in Figure 3. Four single-pass fillet welds were deposited sequentially in a counter-clockwise order.

A common problem was encountered with both types of restrained tests. The bead weld in the Lehigh tests and the fillet welds in the cruciform tests were difficult to deposit. In both cases, 'arc-blow', a condition of arc instability due to weldment geometry, caused most of the weld beads to have surface porosity. All the electrodes in the cruciform tests were baked properly. The electrodes for Lehigh Tests 5 and 6 were wetted to embrittle the weld metal. The electrodes used for the other Lehigh tests were properly baked. Lehigh Test 4 fractured immediately upon completion of the weld bead. Therefore, a second 
weld bead was deposited over the fractured weld.

\section{DISCUSSION OF RESULTS}

The weldments of the first series of tests were examined ultrasonically using the pulse-echo, angle-beam method. Slag inclusions were detected in the Test 2 and 4 weldments. Crack indications were present in the weld of Test 5 . The welds of Tests 1 and 3 contained no rejectionable defects. The weld of Test 6 had a large amount of undercutting caused by excess slag and could not be examined by ultrasonics.

Figure 4 shows the 'in-cooling' AE rate monitoring of the weld tests. This type of testing provides a good indication of defects and their relative activity. Defective welds containing slag inclusions (Welds 2, 4, and 6) showed higher AE rates than acceptable welds (Welds 1 and 3) for periods up to 3 hours after welding was completed. Slag inclusions were typified by continuous AE activity which was very intense for a 2 -hour period after the weld was completed.

$A E$ activity in Test Weld 5 differed from the others. Unfortunately, the recording device failed to function properly during the initial part of the 'in-cooling' process, and those data were lost. Acoustic emissions occurred in random bursts characteristic of crack propagation and(or) possibly martensite transformation (7).

These initial tests indicated that $A E$ monitoring had potential as a nondestructive evaluation tool. However, equipment limitations prevented the detection of hot-cracking which would occur 'in-process'. Therefore, this study was focused on cold-cracking of welds which occurs 'in-cooling'.

On completion of the AE monitoring of the butt-welded high-strength steel plates, the weld beads were visually inspected for surface fractures. No cracks were detected. The cruciform and Lehigh specimens were stress-relieved and sliced into 1-inch (25-mm) thick specimens transverse to the weld. The sections were polished and etched, using nital, and then microscopically examined for cracks. Cracking was recorded as the percent through the shortest possible plane that would lead to complete fracture of the weld. The total $A E$ count and duration were accumulated and the final results are shown on Tables 1 and 2.

Equipment problems prevented a good correlation of total $A E$, counts among the butt-welded A 514 tests. The behavior of AE count-vs-time after welding (in-cooling) for Tests $1,3,5$, and 6 is shown in Figure 5 . The cruciform specimens had much longer 
periods of $\mathrm{AE}$ activity. In most cases, the cruciform specimens emitted larger amounts of acoustic emissions than the butt-welded plates. When considered on a per-electrode basis, which presumes $A E$ activity due to solidification kinetics and plastic deformation can be compared based on the relative amounts of weld metal deposited ( 30 electrodes on the butt-welded plates, four electrodes on the cruciform specimens, and one electrode on the Lehigh specimens), as shown in Figure 6, this contrast is more readily evident.

Equipment problems also adversely affected the data for butt-welded A 588 specimens. However, the duration of $A E$ activity for Tests 2,3,4, and 6 correspond closely. Figure 7 shows the behavior of AE counts-vs-time after welding (in-cooling) for the butt-welded A 588 specimens. Considering that Lehigh Test No. 1 fractured prior to AE monitoring, a good correlation exists between a high total $A E$ activity and fracture. However, there is no direct correlation between the duration of $A E$ activity and fracture. The Lehigh specimens had shorter periods of AE activity than the butt-welded specimens. The Lehigh specimens had significantly higher total $A E$ counts per electrode deposited than the butt-welded A 588 plates as shown in Figure 8. The butt-welded A 588 plates had longer periods of $A E$ activity than the $A 514$ butt weldments. Conversely, the restrained cruciform weldments had much longer periods of acoustic emission activity than the Lehigh specimens.

Cracking was a major source of acoustic emission in the restrained specimens. Fractured Lehigh specimens, which were monitored successfully, produced more $A E$ activity than specimens which had little or no fractures. The increase in the total $A E$ count with cracking is also apparent in the cruciform tests. As shown in Figures 9 and 10, the Lehigh specimens fractured by a ductile tear in the weld metal, due to the high tensile residual forces. The cruciform welds, as shown in Figure 11, fractured by crack growth from re-entrant notches created at faying faces of the steel plates. These cracks grew in lowenergy paths on the third and fourth weld beads between columnar dendritic grains created by the weld solidification process.

Hartbower used acoustic emission to monitor newly welded cruciform specimens of high-strength steel (4). AE activity was detected for periods of up to 440 hours after welding. However, no clear correlations were made between acoustic emission caused by cracking and AE activity due to other sources. Previous tests for delayed cracking of Lehigh tests, using less-sensitive equipment, showed fracture activity similar in duration to the periods of AE activity measured in this study (8). Numerous correlations do exist between 
cracking in metals and acoustic emissions during mechanical tests.

The long duration of $A E$ activity from specimens that did not fracture cannot be explained by the solidification kinetics of steel. Speich and others have shown that the transformation of martensite is the sole thermal transformation product of austenite capable of causing acoustic emission (9). Temperature measurements taken during this study indicate that most of this activity should be completed within 24 hours after the weld is made. A possible source of this long-term $A E$ activity could be the relaxation or readjustment of residual stresses within the weldment.

\section{CONCLUSIONS}

AE monitoring of welds 'in-cooling' has been found to be a promising tool for investigating the dynamic behavior of weldments. It has shown the ability to detect delayed cracking. $A E$ testing may also provide information on the toughness and residual stresses in unflawed weldments. However, further work is required to verify this statement. The following $A E$ behavior was observed during these tests:

1. Acoustic emissions were generated for long periods (up to 265 hours) after welding was completed.

2. The source of a large quantity of emissions generated by welding are not directly related to cracking.

3. A quantitative relationship exists between acoustic emissions and cracking, especially with restrained welds.

4. The duration of $A E$ activity is not clearly related to cracking.

5. On a per-electrode-deposited basis, high-stressed welds produced more emissions than low-stressed welds.

6. Embedded gross defects could be detected by AE monitoring 'in-cooling'.

\section{REFERENCES}

1. D'Annessa, A. T. and Owens, J. S.; Acoustic Emission Characterization of Heat Treat Cracking in Rene 41 Weldments; Welding Journal, Vol 51, March 1972, pp 156s-168s

2. Romerell, D. M.; Acoustic Emission Weld Monitoring of Nuclear Components; Welding Journal, Vol 52, February 1973, pp 81s-87s.

3. Jolly, W. D.; The Application of Acoustic Emission to In-Process Inspection of Welds; Materials Evaluation, Vol 28, June 1970, pp 135-139, 144. 
4. Hartbower, C. E., Reuter, W. G., Morris, C. F., and Crimmins, P. P.; Acoustic Emission for the Detection of Weld and Stress Corrosion Cracking; Acoustic Emission, STP 505, American Society for Testing and Materials, 1972, pp 187-221.

5. Jolly, W. D.; Acoustic Emission Exposes Cracks during the Welding Process; Welding Journal, Vol 48, January 1969, pp 21-27.

6. Prine, D.; NDT of Welds by Acoustic Emission; Technical Report DE 73-X, Dunnegan/Endevco Corporation.

7. Speich, G. R. and Fisher, R. M.; Acoustic Emission During Martensite Formation; Acoustic Emission, STP 505, American Society for Testing and Materials, 1972, pp 140-151.

8. Torok, T. E. and Stout, R. D.; Relation of Dilatometric Characteristics of Stee/s to Delayed Cracking in Welds; Welding Journal, American Welding Society, December 1965, pp 529s-544s.

9. Speich, G. R. and Schwoeble, A. J.; Acoustic Emission During Phase Transformation in Steel; Monitoring Structural Integrity by Acoustic Emission, STP 571, American Society for Testing and Materials, 1975, pp 40-58. 


\section{TABLE 1. RESULTS OF TESTS USING ASTM A 514 STEEL}

\begin{tabular}{|c|c|c|c|c|}
\hline $\begin{array}{l}\text { TEST TYPE } \\
\text { AND NUMBER }\end{array}$ & $\begin{array}{l}\text { WELDING ELECTRODE } \\
\text { AND CONDITION }\end{array}$ & CONDITION OF WELD & $\begin{array}{l}\text { DURATION OF ACOUSTIC } \\
\text { EMISSION ACTIVITY (HOURS) }\end{array}$ & $\begin{array}{l}\text { TOTAL ACCUMULATED } \\
\text { ACOUSTIC EMISSION }\end{array}$ \\
\hline Butt-Weld 1 & AWS E1 1018-M, Dried & $\begin{array}{l}\text { Much porosity, } \\
\text { No surface cracking }\end{array}$ & 75 & 207,000 \\
\hline Butt-Weld 2 & AWS E11018-M, Dried & $\begin{array}{l}\text { Much porosity, } \\
\text { No sturface cracking }\end{array}$ & 102 & a \\
\hline Butt-Weld 3 & AWS E11018-M, Dried & $\begin{array}{l}\text { Random porosity, } \\
\text { No surface cracking }\end{array}$ & 34 & 99,500 \\
\hline Butt-Weld 4 & AWS E11018-M, Dried & $\begin{array}{l}\text { Random porosity, } \\
\text { No surface cracking }\end{array}$ & 64 & $b$ \\
\hline Butt-Weld 5 & AWS E11018-M, Dried ${ }^{\mathrm{C}}$ & $\begin{array}{l}\text { Little porosity, } \\
\text { No surface cracking }\end{array}$ & 65 & 763,000 \\
\hline Butt-Weld 6 & AWS E11018-M, Dried ${ }^{c}$ & $\begin{array}{l}\text { Little porosity, } \\
\text { No surface cracking }\end{array}$ & 53 & 112,000 \\
\hline Cruciform I & AWS E11018-M, Dried & $\begin{array}{l}\text { Much porosity, } \\
13 \% \text { cracking }\end{array}$ & 265 & 514,000 \\
\hline Cruciform 2 & AWS E11018-M, Dried & $\begin{array}{l}\text { Much porosity, } \\
20 \% \text { cracking }\end{array}$ & 260 & 717,000 \\
\hline Cruciform 3 & AWS E11018-M, Dried & $\begin{array}{l}\text { Random porosity, } \\
8 \% \text { cracking }\end{array}$ & 259 & 536,000 \\
\hline Cruciform 4 & AWS E11018-M, Dried & $\begin{array}{l}\text { Random porosity, } \\
2 \% \text { cracking }\end{array}$ & 242 & 394,000 \\
\hline
\end{tabular}

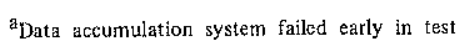

${ }^{b}$ Data accumulation system failed early in test

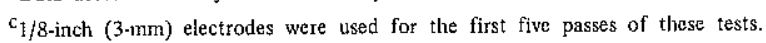




\section{TABLE 2. RESULTS OF TESTS USING ASTM A 588 STEEL}

\begin{tabular}{|c|c|c|c|c|}
\hline $\begin{array}{l}\text { TEST TYPE } \\
\text { AND NUMBER }\end{array}$ & $\begin{array}{l}\text { WELDING ELECTRODE } \\
\text { AND CONDITION }\end{array}$ & CONDITION OF WELD & $\begin{array}{l}\text { DURATION OF ACOUSTIC } \\
\text { EMISSION ACTIVITY (HOURS) }\end{array}$ & $\begin{array}{l}\text { TOTAL ACCUMULATED } \\
\text { ACOUSTIC EMISSION }\end{array}$ \\
\hline Butt-Weld 1 & AWS E8016, Dried & $\begin{array}{l}\text { Good test, no } \\
\text { surface cracking }\end{array}$ & $264^{2}$ & $1,275,000^{\mathrm{b}}$ \\
\hline Butt-Weld 2 & AWS E8016, Wet & $\begin{array}{l}\text { Random porosity, } \\
\text { no surface cracking }\end{array}$ & 139 & $302,400^{\mathrm{C}}$ \\
\hline Butt-Weld 3 & AWS E7016, Dried & $\begin{array}{l}\text { Good test, no } \\
\text { surface cracking }\end{array}$ & 141.5 & $996,000^{d}$ \\
\hline Butt-Weld 4 & AWS E8016, Dried & $\begin{array}{l}\text { Good test, no } \\
\text { surface cracking }\end{array}$ & 141 & 503,000 \\
\hline Butt-Weld 5 & AWS E8016, Unbaked & $\begin{array}{l}\text { Good test, no } \\
\text { surface cracking }\end{array}$ & $65^{\mathrm{e}}$ & $1,030,000^{\mathrm{e}}$ \\
\hline Butt-Weld 6 & AWS E8016, Dried & $\begin{array}{l}\text { Good test, no } \\
\text { surface cracking }\end{array}$ & 138 & 191,900 \\
\hline Lehigh 1 & AWS E8016, Dried & $\begin{array}{l}\text { Much porosity, } \\
\text { complete fracture }\end{array}$ & 91 & 105,000 \\
\hline Lehigh 2 & AWS E8016, Dried & $\begin{array}{l}\text { Much porosity, } \\
2 \% \text { fracture }\end{array}$ & 91 & 65,000 \\
\hline Lehigh 3 & AWS E8016, Dried & $\begin{array}{l}\text { Much porosity, } \\
2 \% \text { fracture }\end{array}$ & 53 & 63,000 \\
\hline Lehigh 4 & AWS E8016, Dried & $\begin{array}{l}\text { Much porosity, } \\
\text { complete fracture }\end{array}$ & 54 & $1,390,000$ \\
\hline Lehigh 5 & AWS E8016, Wet & $\begin{array}{l}\text { Much porosity, } \\
\text { complete fracture }\end{array}$ & 41 & $1,261,000$ \\
\hline Lehigh 6 & AWS E8016, Wet & $\begin{array}{l}\text { Little porosity } \\
5 \% \text { fracture }\end{array}$ & 74 & 141,000 \\
\hline
\end{tabular}

${ }^{\mathrm{a}}$ System gain for this test was $85 \mathrm{~dB}$, for the remaining tests, the gain was $80 \mathrm{~dB}$.

${ }^{b}$ Data accumulation system failed at 52 hours.

${ }^{c}$ Data accumulation system failed at 56 hours.

${ }^{d}$ Data accumulation system failed at 14 hours.

eAcoustic emission system failed at 65 hours.

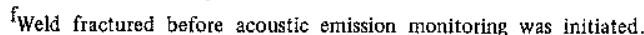

g weld fractured on completion; a second pass was deposited before acoustic emission monitoring. 


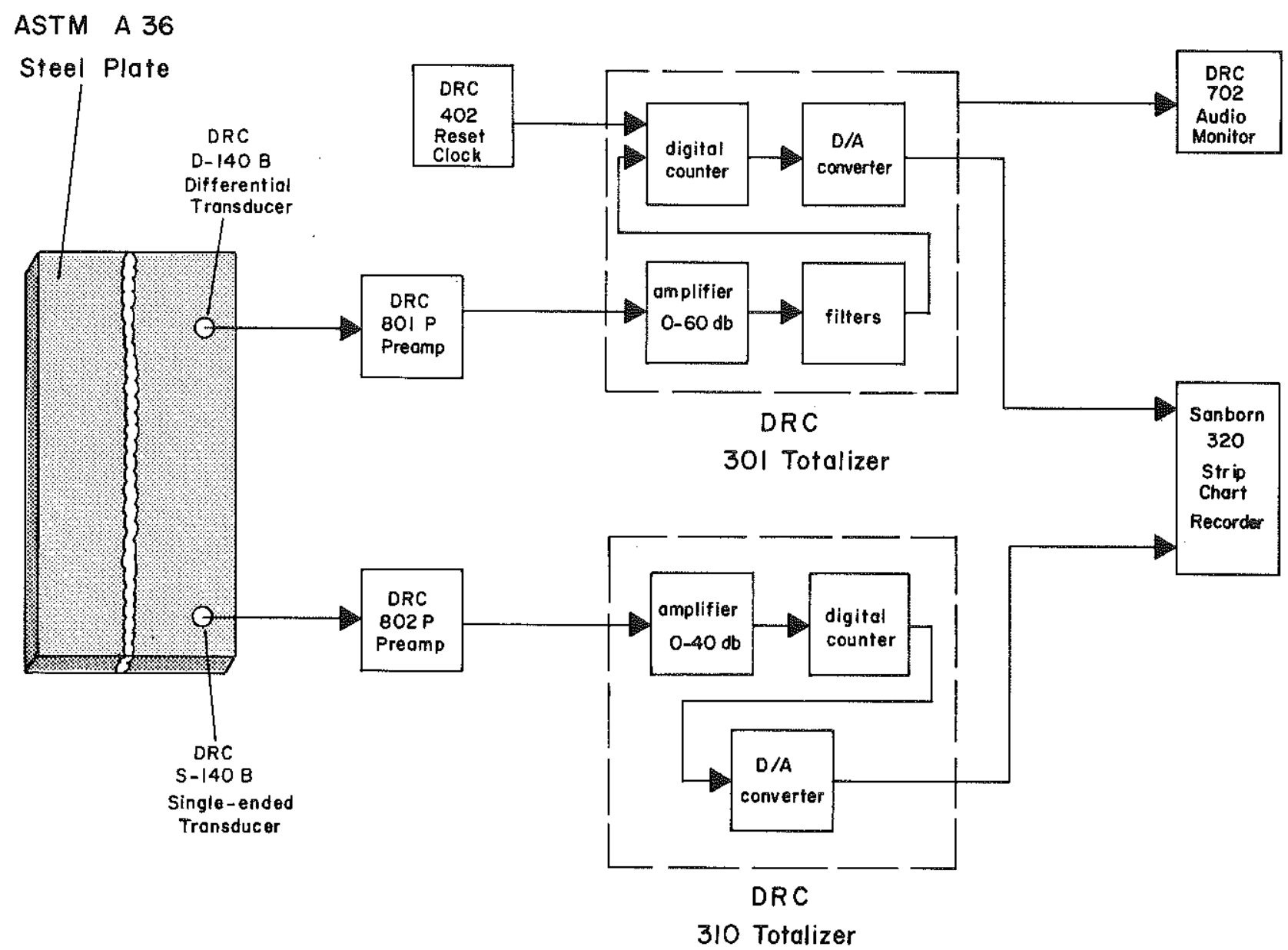

Figure 1. Acoustic Emission Detection System Used in Weld Tests. 
Figure 2. Lehigh Restraint Specimen.

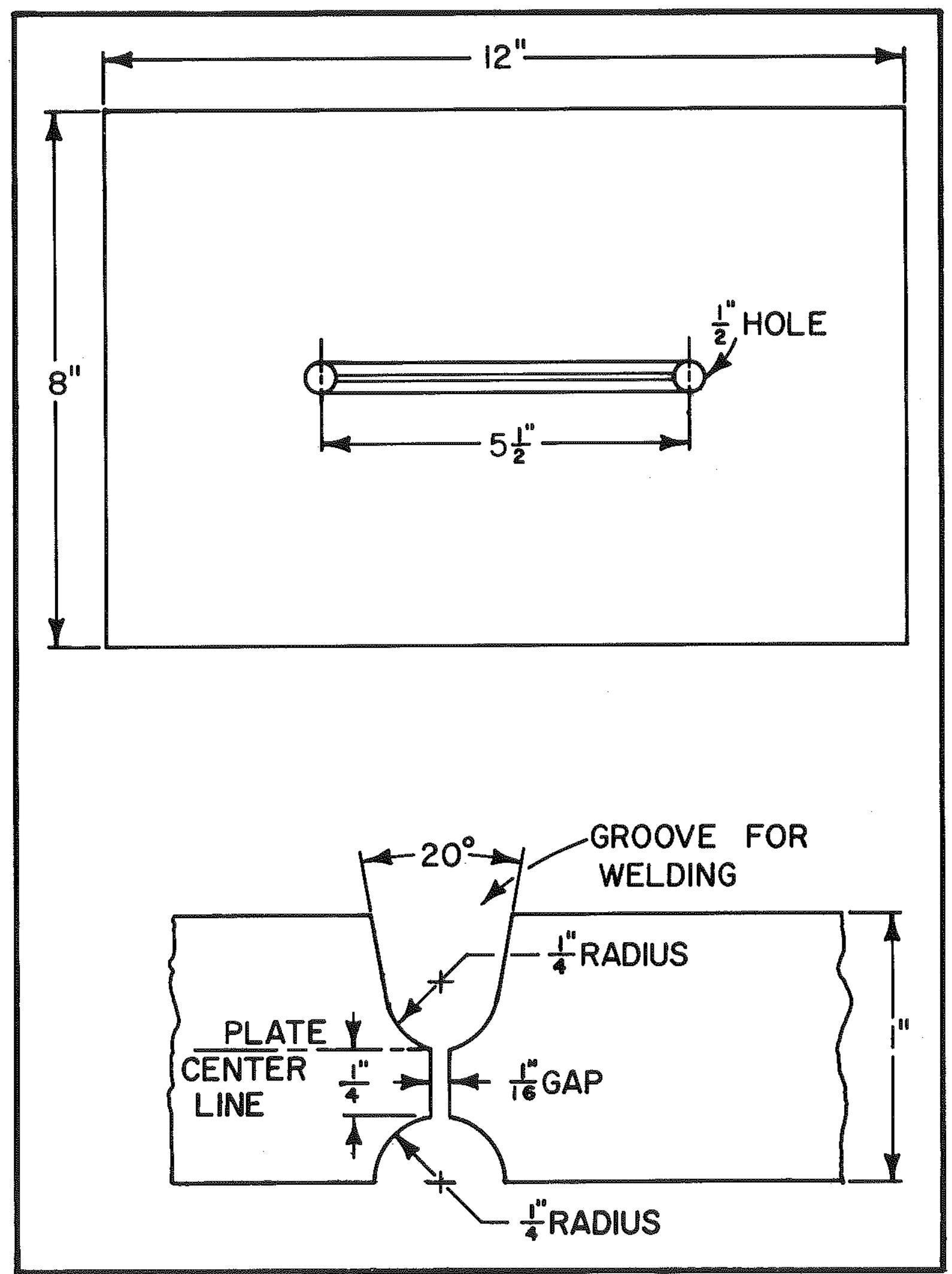




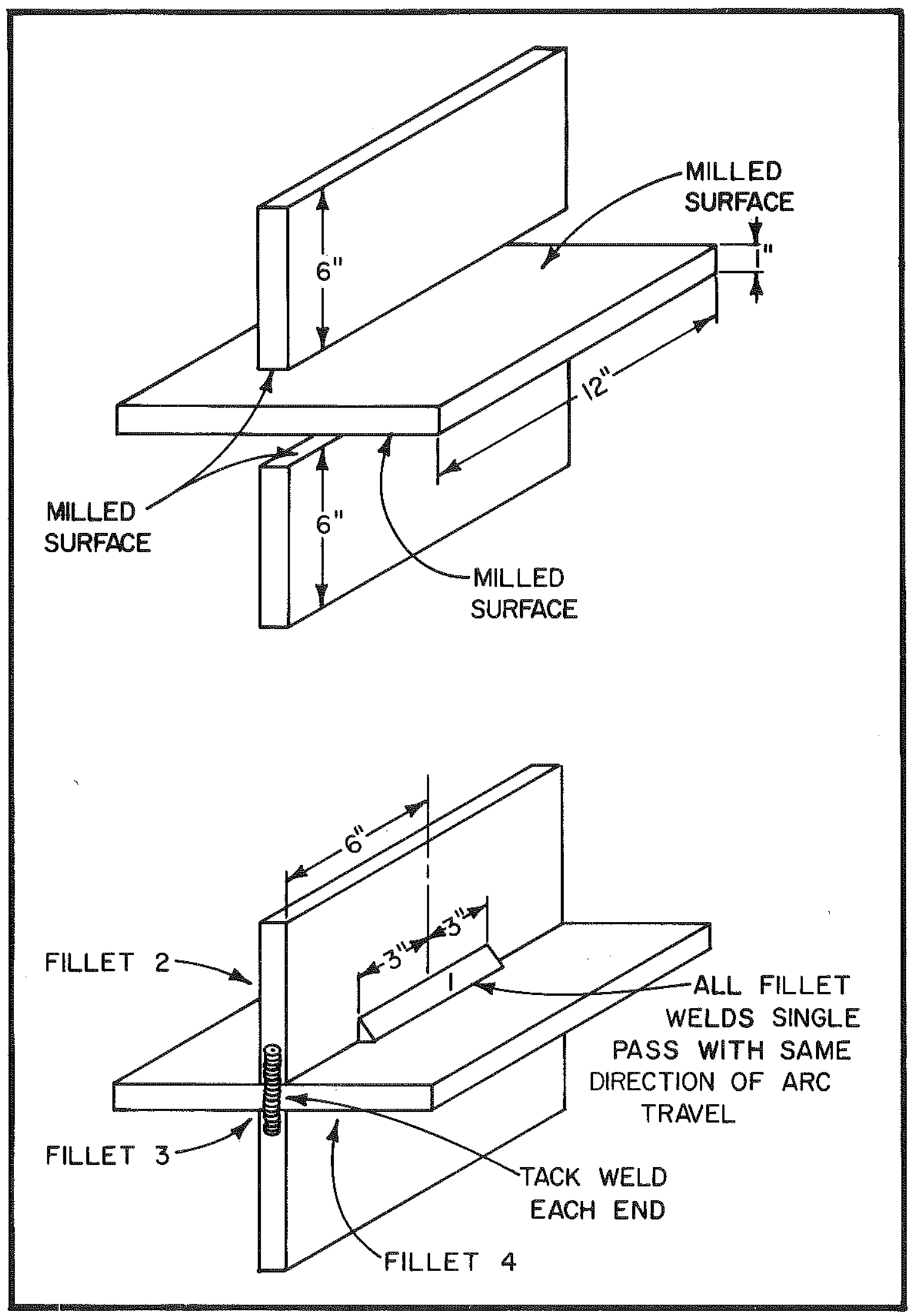

Figure 3. Cruciform Restraint Specimen. 


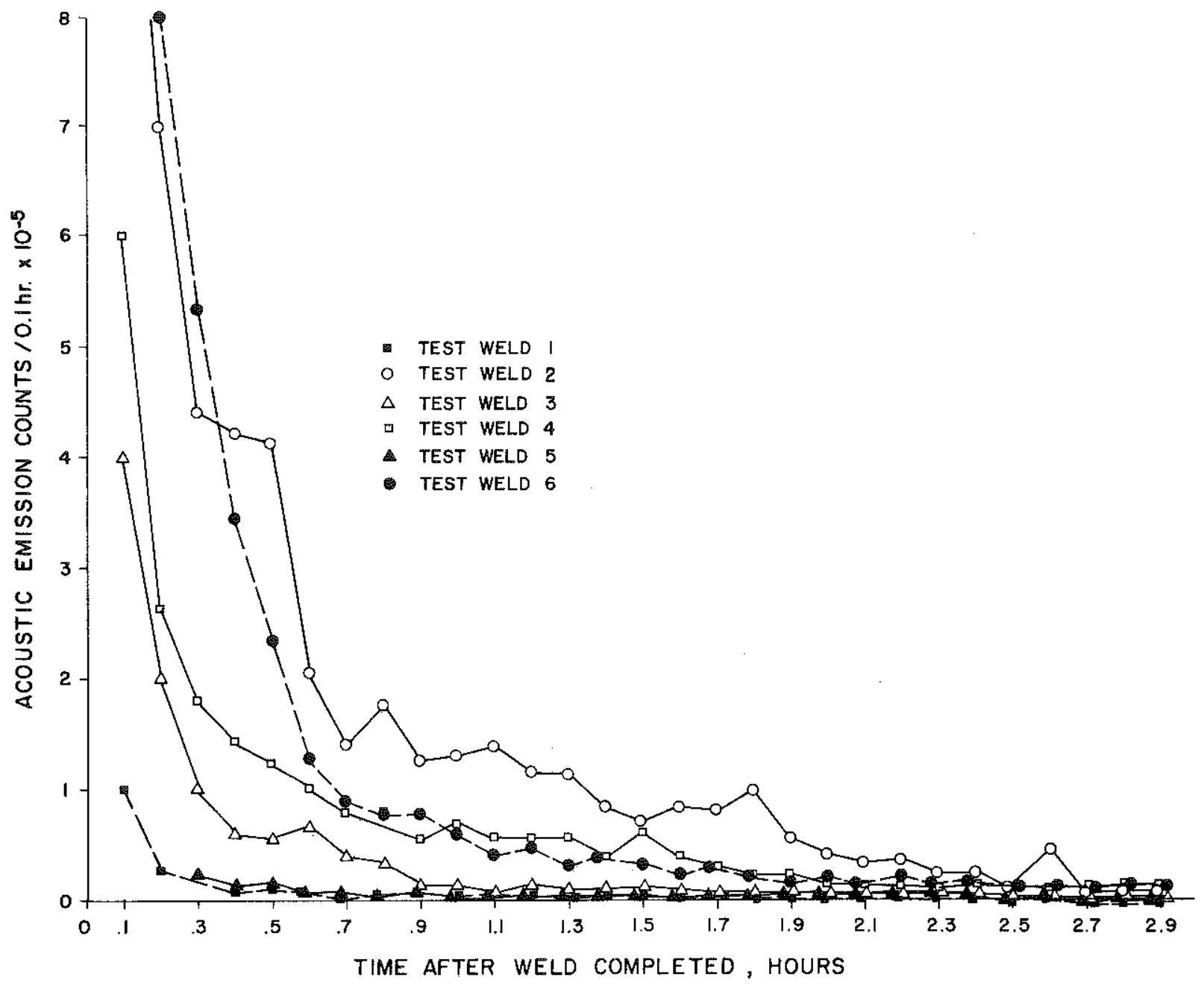

Figure 4. 'In-cooling' AE Rates vs Cooling Time for Test Welds 1 through 6. 


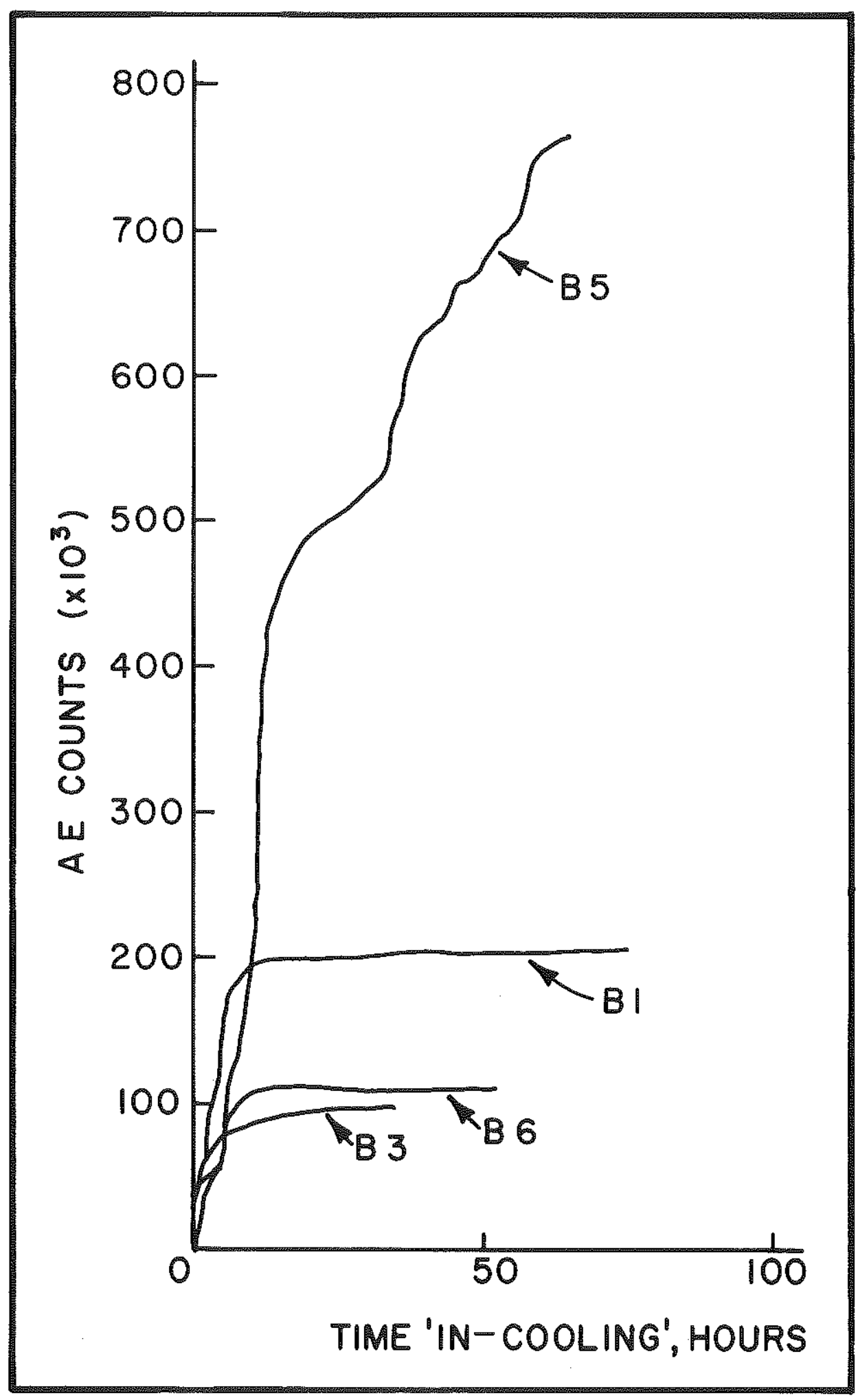

Figure 5. Total AE Counts versus Time for Butt-welded, ASTM A 514 Plates 'In-cooling'. 


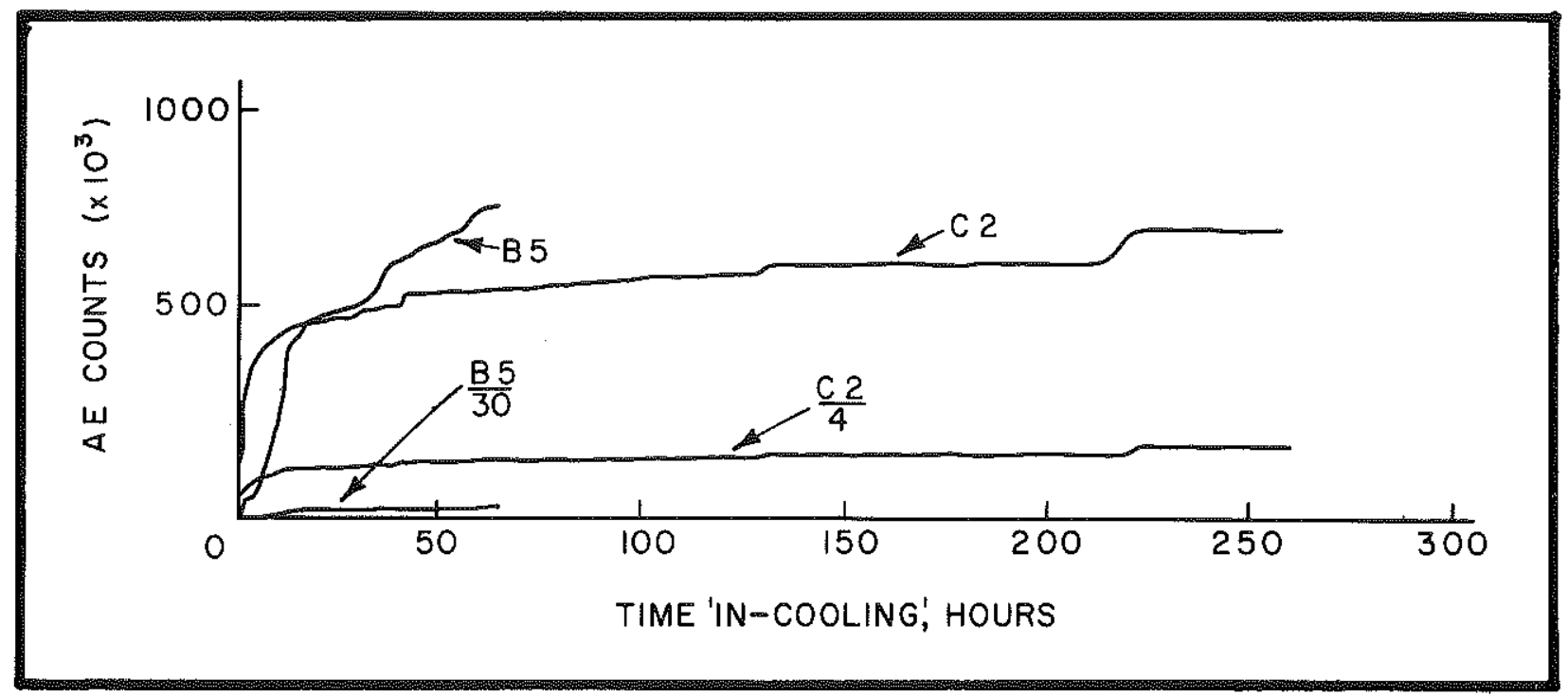

Figure 6. Total AE Count Behavior of ASTM A 514, Butt-welded and Cruciform Specimens on a per Electrode Basis. 


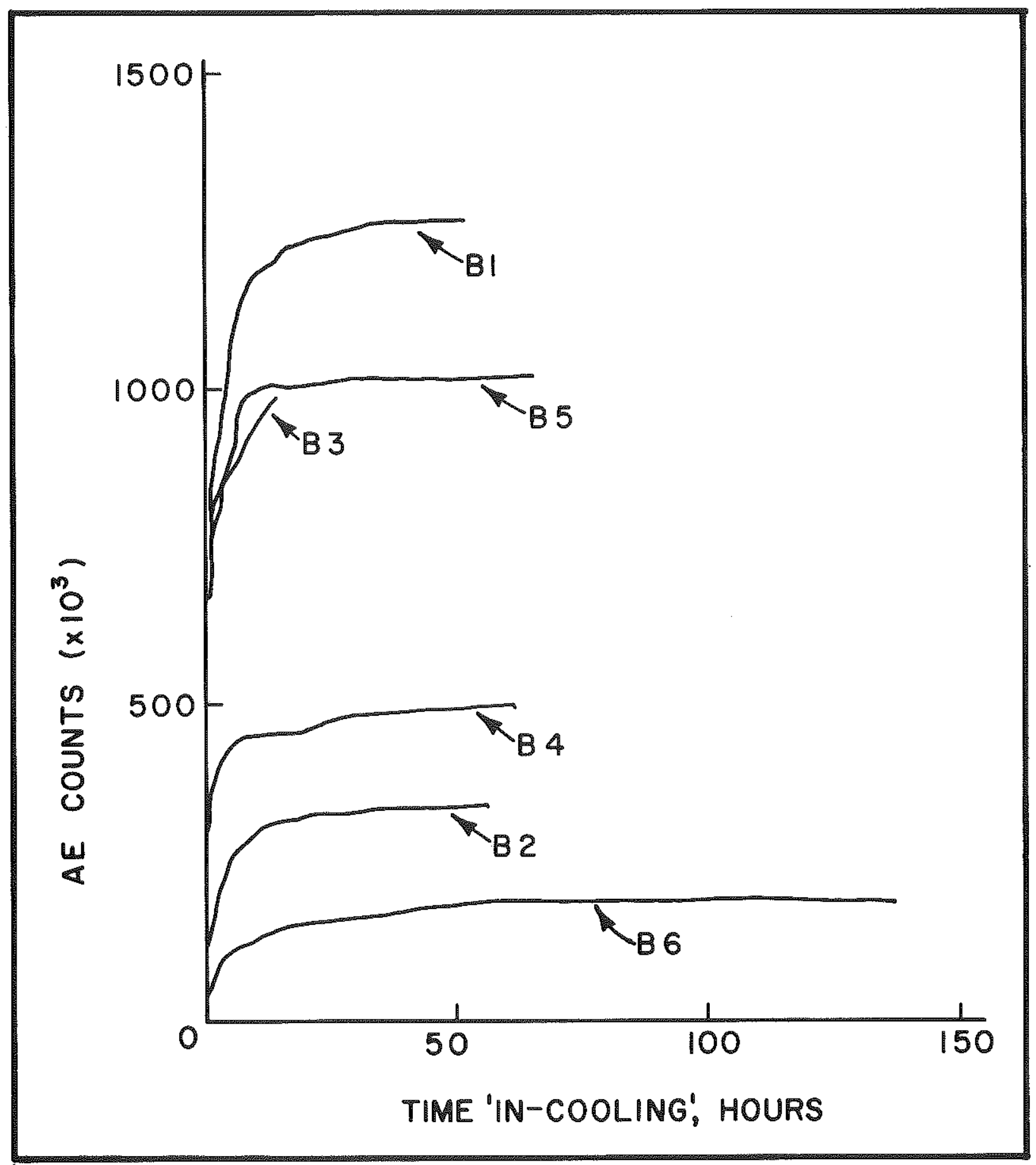

Figure 7. AE Totel Cownts vs Time for Butt-welded ASTM A 588 Plates 'In-cooling'. 


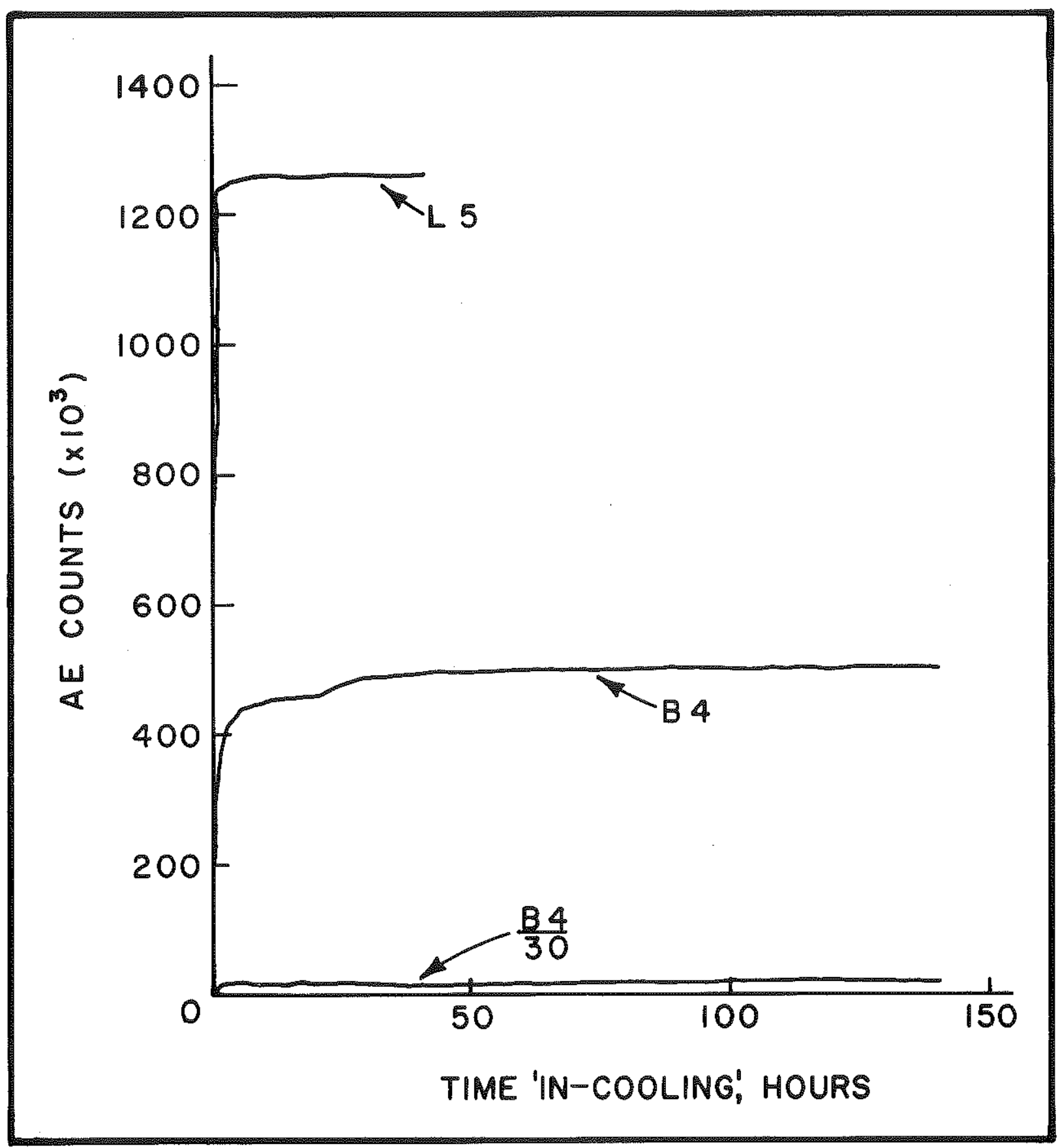

Figure 8. Total AE Count Behavior of ASTM A 588, Butt-welded and Lehigh Specimens on a per Electrode Basis. 


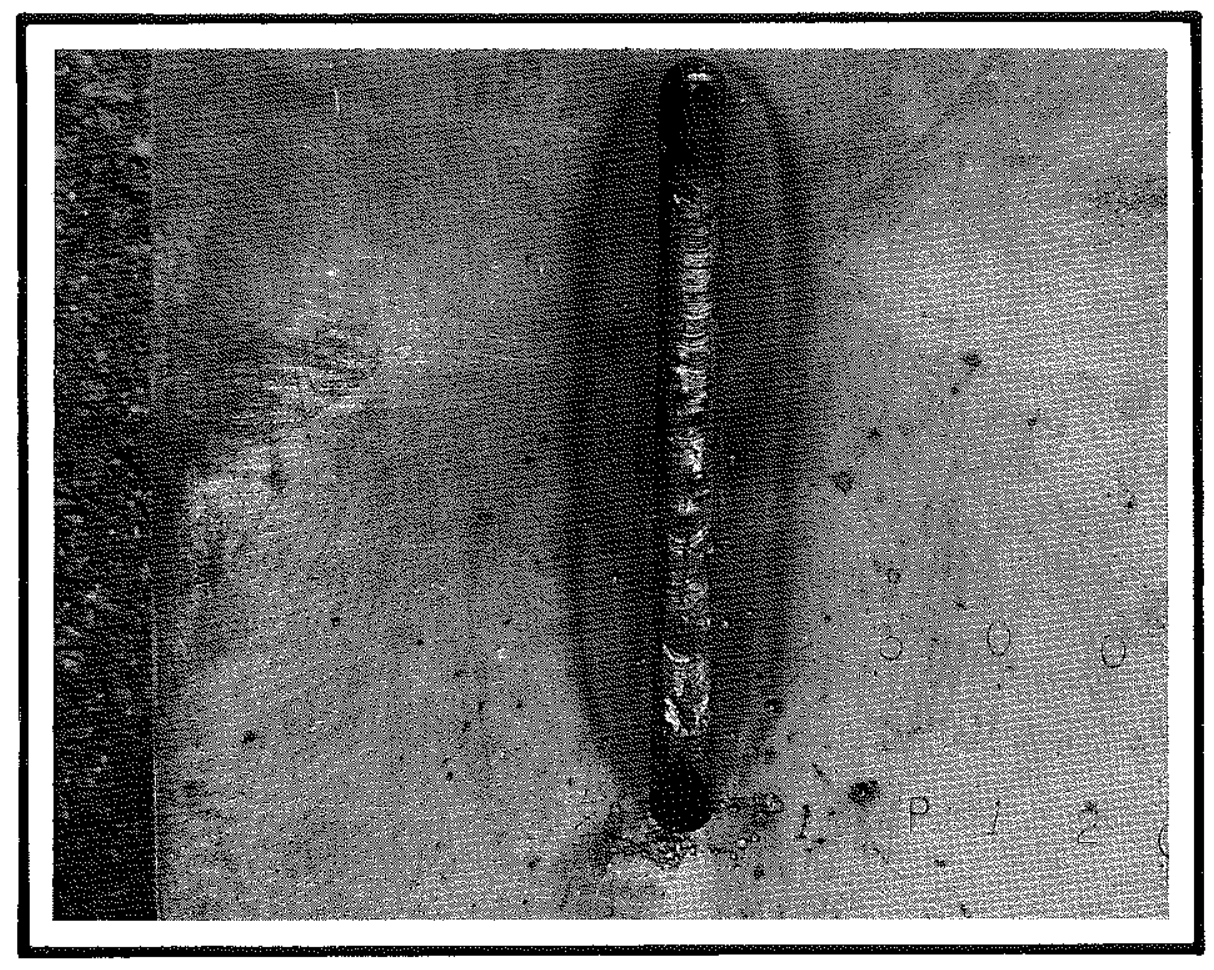

Figure 9. Fracture in Lehigh Specimen No. 1. 
Figure 10. Cross-sectional View of Fracture in Lehigh Specimen No. 1.
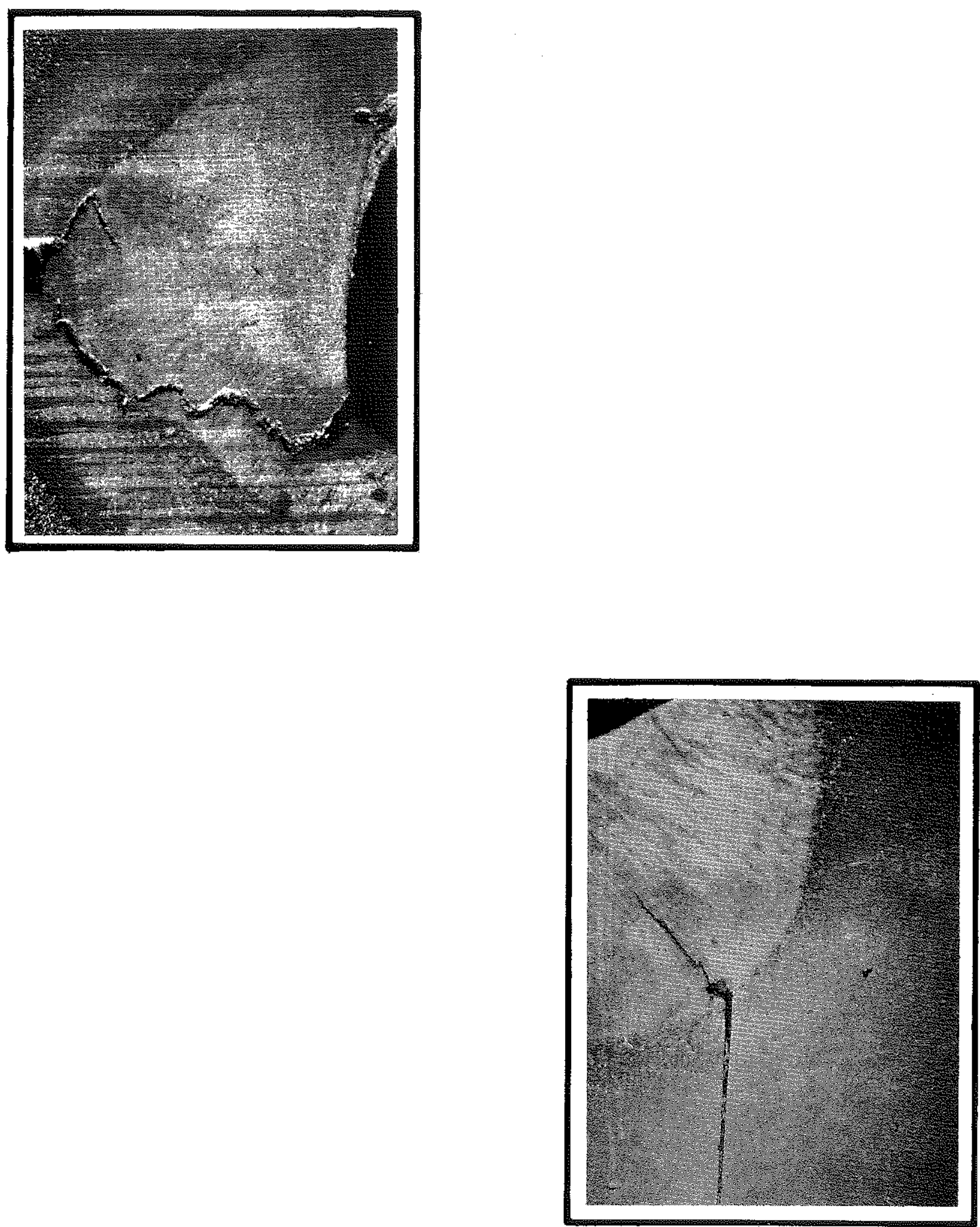

Figure 11. Cross-sectional View of Fracture in Cruciform Specimen No. 2. 